\title{
Level of modern health care seeking behaviors among mothers having under five children in Dangila town, north West Ethiopia, 2016: a cross sectional study
}

\author{
Amare Belachew Dagnew ${ }^{1}$, Tilahun Tewabe ${ }^{1 *}$ and Rajalakshmi Murugan ${ }^{2}$
}

\begin{abstract}
Background: Health seeking behavior is an action taken by an individual who perceive to have a health problem. In most developing countries including Ethiopia the health of the children is strongly dependant on maternal health care behavior. Most childhood morbidities and mortalities are associated with low level of mothers health care seeking behavior. Therefore, the objective of this study was to assess level of modern health care seeking behavior among mothers having under five children in Dangila town, North West Ethiopia.

Methods: Community based quantitative cross-sectional study was conducted from April 15 to May 15, 2016. Systematic random sampling technique was used to select study participants. A total of 273 mothers with children less than five years were included in this study. The data was collected from all five Kebeles using interviewer administered questionnaire. Descriptive and inferential statistics were used to present the data. Both bivariate and multivariate logistic regression analyses were used to identify factors associated with level of modern health care seeking behavior.

Results: Prevalence of modern health care seeking behavior was $82.1 \%$. Age of mothers ( $A O R=2.4(1.1,5.3)$, age of the child (AOR $=6.7(2.8,22.2)$, severity of illness ( $A O R=5.2(1.2,22.6)$ and family number ( $A O R=6.4(2.1,20.2)$ were predictors of modern health care seeking behavior among mothers.

Conclusions: Majority of the mothers preferred to take their children to modern health care when they got illness. Age of children, age of mother, number of family and severity of illness were the determinant factors for modern health care seeking behavior. Therefore, health care services should be strengthened at community level through community integrated management of childhood illness, information, education communication / behavioral change communication strategies to improve mothers health care seeking behaviors.
\end{abstract}

Keywords: Modern health care seeking behavior, Under five children, Dangila, North West Ethiopia

\section{Background}

Globally, 6.3 million children under the age of five years died each year. Sub-Saharan countries are among the regions where under five mortalities are highest [1].

The Ethiopian demographic health survey (EDHS 2011) showed under five mortality rates were higher among children from poor and non educated families. The risk of child death was higher in childrens who have uneducated mother [2].

\footnotetext{
* Correspondence: bezatewabe01@gmail.com

${ }^{1}$ College of Medicine and Health science, Bahir Dar University, Bahir Dar, Ethiopia Full list of author information is available at the end of the article
}

Although modern health care interventions have the potential to substantially reduce childhood mortalities, a large number of children in developing countries died without ever reaching in health care facilities. Inability to recognize potentially life threatening conditions and pluralistic care seeking practices were the factors that make mothers to delay in seeking modern care timely. This delay affected child health significantly and leads to complications that make the medical care less effective [3].

Treatments of common childhood illness like diarrhea, malaria and pneumonia are usually very effective if the care is sought on time. However, to implement ongoing

(c) The Author(s). 2018 Open Access This article is distributed under the terms of the Creative Commons Attribution 4.0 International License (http://creativecommons.org/licenses/by/4.0/), which permits unrestricted use, distribution, and 
programs and to facilitate appropriate care remained as a challenge now a days [4].

Therefore, the morbidity and mortalities from these diseases can be reduced when care is sought early. The ability of caregivers to recognize and seek appropriate care of childhood illnesses is instrumental in reducing childhood deaths. Appropriate medical care seeking can prevent a significant number of childhood deaths and complications $[5,6]$.

Therefore, the purpose of this study was to assess mother's modern health care seeking behavior for childhood illness in Dangila town, North West Ethiopia.

\section{Methods}

Community based quantitative cross sectional study was conducted from April 15 to May 15, 2016. The study was conducted in Dangila town, Awi zone, Amhara Regional State, Ethiopia. It is located $485 \mathrm{~km}$ Northwest from Addis Ababa and $78 \mathrm{~km}$ from Bahir Dar, the capital city of Amhara region. The town has a total of five kebeles. It has a total of 5, 256 households and 30, 147 peoples and 1937 were under five children. There is a health center and two private clinics in the town.

The sample size was calculated using single population proportion formula by considering the following assumptions: prevalence $(\mathrm{P}) 73 \%$, which is the prevalence of health seeking behavior in Bahir Dar town, North West Ethiopia [7], confidence level (CL) 95\%, margin of error (d) $5 \%$ and after considering $10 \%$ non response rate the final sample size became 273 . Using systematic random sampling technique, by selecting one from every seven households, a total of 273 households with under five children were selected. The first house hold were determined using lottery method which was three..

A structured interviewer administered questionnaire was used to collect data from mothers with under five children. It was constructed by adopting from previous research done on similar topics and modified accordingly. Four diploma nurses were recruited as data collectors and two Bachelor of Science nurses were recruited as supervisors. All data collectors and supervisors were oriented and trained on how to interview and record the data one day before the survey.

The collected data was checked manually for completeness and consistencies. Then it was coded, entered in EPI Info version 3.5.3 and exported to SPSS version 20 for analysis. Descriptive statistics was used to summarize the sociodemographic characteristics' of the study participants and level of modern health care seeking behavior. To identify factors associated with mothers modern health care seeking behavior binary logistic regression analysis was carried out. Strength of association was measured using odds ratio and $95 \%$ confidence interval. Statistical significance was declared at $P$ value $<0.05$.

\section{Ethics approval and consent to participate}

Ethical clearance was obtained from AAU, department of nursing and midwifery research committee. Each study participant was adequately informed about the objective of the study, anticipated benefits and risk of the study by their respective data collector. Verbal consent was obtained from study participants for protecting autonomy and ensuring confidentiality .

\section{Results}

\section{Socio demographic characteristics}

In this study, 273 mothers were participated. Above one third $102(37.4 \%)$ of mothers were within the age group of 25 to 29 years with mean age of 28 years. About 66 (24.2\%) mothers were unable to read and write, 220 (80.6\%) were married and 134 (49.1\%) were house wife's. Regarding the average household income, about99 (36.3\%) earn greater than 2000 Ethiopian birr per month. Most249 (91.2\%) mothers had less than or equal to five family members. About 229 (83.9\%) mothers had one under five children in the house. With regard to youngest child, 146 (53.6) were females and 190 (69.6\%) were above one year (Table 1).

\section{Health seeking behavior}

The overall four weeks prevalence of common childhood illness complained by mothers were: cough $70(26 \%)$, fever 65(24\%) and diarrhea 55 (20\%). Among 224 mothers, 177 (90\%) of mothers made decision for seeking medical care by their own when their child got illness. While for $17(7.6 \%)$ cases the decision was made by their husband. The overall prevalence of modern health care seeking behavior of mothers was $82.1 \%$. The main reasons mentioned for not seeking modern health care were: perceiving as illness is mild (24.5\%), thought as sickness is incurable (16.3\%), shortage of money (16.3\%) and long period of waiting for medical services (14.3\%) (Table 2).

Regarding to perception of illness, nearly half 129 (47.3\%) of mothers perceived their child illness was moderate, and about 156 (57.1\%) mothers identifies the severity of illness by viewing different symptoms. From all, only $8(2.9 \%)$ mothers took their child to traditional healers for treatment and three of them used traditional treatment since they believed that disease doesn't cure by modern health care (Table 3 ).

\section{Factors affecting mothers modern health care seeking behavior}

In the bivariate logistic regression analysis: age of mother, occupational status, marital status, age of child, number of family and disease characteristics were statistically associated with modern health care seeking behavior.

In final multivariate analysis: age of the mother, age of the child, number of family numbers and perceived severity 
Table 1 Socio demographic characteristics of mothers/caregivers and under five children are in Dangila town, Northwest Ethiopia, 2015

\begin{tabular}{|c|c|c|c|}
\hline Variable & Response & $\begin{array}{l}\text { Frequency } \\
(N=273)\end{array}$ & Percent (\%) \\
\hline \multirow{4}{*}{$\begin{array}{l}\text { Age of mothers/ } \\
\text { caregivers }\end{array}$} & $<25$ years & 55 & 20.1 \\
\hline & $25-29$ years & 102 & 37.4 \\
\hline & 30-34 years & 65 & 23.8 \\
\hline & $\geq 35$ years & 51 & 18.7 \\
\hline \multirow[t]{2}{*}{ Age of child } & $\leq 1$ years & 83 & 30.4 \\
\hline & $>1-5$ years & 190 & 69.6 \\
\hline \multirow[t]{2}{*}{ Sex of children } & Male & 127 & 46.5 \\
\hline & Female & 146 & 53.5 \\
\hline \multirow{3}{*}{$\begin{array}{l}\text { Marital status of } \\
\text { mothers. }\end{array}$} & Married & 220 & 80.6 \\
\hline & Divorced & 43 & 15.8 \\
\hline & Widowed & 10 & 3.7 \\
\hline \multirow{2}{*}{$\begin{array}{l}\text { Religion of Mothers/ } \\
\text { care givers. }\end{array}$} & Orthodox & 220 & 80.6 \\
\hline & Muslim & 53 & 19.4 \\
\hline \multirow{2}{*}{$\begin{array}{l}\text { Ethnicity of mothers/ } \\
\text { caregivers }\end{array}$} & Amhara & 173 & 63.4 \\
\hline & Others $^{a}$ & 100 & 36.6 \\
\hline \multirow[t]{5}{*}{ Educational status } & $\begin{array}{l}\text { Unable to Write } \\
\text { and read. }\end{array}$ & 66 & 24.2 \\
\hline & Read and write & 37 & 13.6 \\
\hline & Primary school & 40 & 14.7 \\
\hline & Secondary school & 58 & 21.2 \\
\hline & College and above & 72 & 26.4 \\
\hline \multirow{4}{*}{$\begin{array}{l}\text { Occupation of mothers/ } \\
\text { care givers. }\end{array}$} & House wife & 134 & 49.1 \\
\hline & Government work & 48 & 17.6 \\
\hline & Merchants & 62 & 22.7 \\
\hline & Labor worker & 29 & 10.6 \\
\hline \multirow[t]{5}{*}{ Monthly income. } & $\leq 500$ & 3 & 1.1 \\
\hline & $501-1000$ & 54 & 19.8 \\
\hline & $1001-1500$ & 56 & 20.5 \\
\hline & $1501-2000$ & 61 & 22.3 \\
\hline & $>2000$ & 99 & 36.3 \\
\hline \multirow[t]{2}{*}{ Family members } & $\leq 5$ & 249 & 91.2 \\
\hline & $>5$ & 24 & 8.8 \\
\hline \multirow{2}{*}{$\begin{array}{l}\text { Number of under } \\
\text { five children }\end{array}$} & 1 & 229 & 83.9 \\
\hline & $>2$ & 44 & 16.1 \\
\hline
\end{tabular}

${ }^{a}$ Tigray, Awe, Oromo

of illness were significantly associated with mothers modern health care seeking behavior.

Maternal age greater than or equal to 28 years were almost 2.4 times more likely to seek modern health care than those mothers less than 28 years $[\mathrm{AOR}=2.4(1.1$, 5.4)]. Mothers who had children less than one years of age were 6.7 times higher to seek modern health care than a mothers who have a child greater than one year's
Table 2 Proportion of common childhood illness among mothers/caregivers with under five children's in Dangila town, Northwest Ethiopia, 2015

\begin{tabular}{|c|c|c|c|}
\hline Variable & & $\begin{array}{l}\text { Frequency } \\
(N=273)\end{array}$ & $\begin{array}{l}\text { Percent } \\
(\%)\end{array}$ \\
\hline \multirow{6}{*}{$\begin{array}{l}\text { Complains of mothers } \\
\text { /care givers. }\end{array}$} & Cough & 70 & 26 \\
\hline & Difficulty of breathing & 31 & 11 \\
\hline & Fever & 65 & 24 \\
\hline & Diarrhea & 55 & 20 \\
\hline & Ear infection & 8 & 3 \\
\hline & $\begin{array}{l}\text { Two and above } \\
\text { symptoms }\end{array}$ & 44 & 16 \\
\hline \multirow{4}{*}{$\begin{array}{l}\text { Decision makers for } \\
\text { medical treatment }\end{array}$} & Mothers & 177 & 79.0 \\
\hline & Fathers & 17 & 7.6 \\
\hline & Grand parents & 5 & 2.2 \\
\hline & $\begin{array}{l}\text { Both mothers and } \\
\text { fathers. }\end{array}$ & 25 & 11.2 \\
\hline \multirow{7}{*}{$\begin{array}{l}\text { Distribution of health } \\
\text { seeking behavior } \\
\text { among mothers/ } \\
\text { care givers }\end{array}$} & Treat with Hole water & 3 & 1.1 \\
\hline & Self treatment at home & 3 & 1.1 \\
\hline & $\begin{array}{l}\text { Take to traditional } \\
\text { treatment }\end{array}$ & 8 & 2.9 \\
\hline & Did nothing & 12 & 4.4 \\
\hline & $\begin{array}{l}\text { Treat the child by buying } \\
\text { from pharmacy or drug } \\
\text { sellers }\end{array}$ & 23 & 8.4 \\
\hline & $\begin{array}{l}\text { Take to private health } \\
\text { facility }\end{array}$ & 45 & 16.5 \\
\hline & $\begin{array}{l}\text { Take to Government } \\
\text { facility }\end{array}$ & 179 & 65.9 \\
\hline \multirow{4}{*}{$\begin{array}{l}\text { Perceived illness } \\
\text { stayed for medical } \\
\text { care among mothers } \\
\text { /care takers }\end{array}$} & $\begin{array}{l}\text { On the same day of } \\
\text { child hood illness }\end{array}$ & 62 & 22.8 \\
\hline & $\begin{array}{l}\text { After one days of } \\
\text { child hood illness }\end{array}$ & 126 & 46.4 \\
\hline & $\begin{array}{l}\text { After two days of } \\
\text { child hood illness }\end{array}$ & 48 & 17.4 \\
\hline & $\begin{array}{l}\text { After three days of } \\
\text { child hood illness }\end{array}$ & 37 & 13.4 \\
\hline \multirow{9}{*}{$\begin{array}{l}\text { Main reasons of } \\
\text { mothers/caregivers } \\
\text { for not seeking } \\
\text { medical care }\end{array}$} & $\begin{array}{l}\text { No treatment for } \\
\text { sickness }\end{array}$ & 6 & 2 \\
\hline & Cost of medical care & 11 & 4.1 \\
\hline & $\begin{array}{l}\text { No trust on health } \\
\text { providers competency }\end{array}$ & 17 & 6.1 \\
\hline & Lack of time & 17 & 6.1 \\
\hline & $\begin{array}{l}\text { Thought it get better } \\
\text { by it self }\end{array}$ & 28 & 10.2 \\
\hline & $\begin{array}{l}\text { Don't get immediate } \\
\text { care / wait for several } \\
\text { times for service }\end{array}$ & 39 & 14.3 \\
\hline & Shortage of money & 44 & 16.3 \\
\hline & $\begin{array}{l}\text { Thought sickness is } \\
\text { incurable }\end{array}$ & 44 & 16.3 \\
\hline & Illness was mild & 67 & 24.5 \\
\hline
\end{tabular}


Table 3 Perception of mothers/caregivers about severity of common childhood illness among mothers/caregivers having under five children's in Dangila town, Northwest Ethiopia, 2015

\begin{tabular}{|c|c|c|c|}
\hline variable & Response & $\begin{array}{l}\text { Frequency } \\
(N=273)\end{array}$ & Percent (\%) \\
\hline \multirow{3}{*}{$\begin{array}{l}\text { Perception of } \\
\text { mothers about } \\
\text { severity of illness. }\end{array}$} & Severe & 125 & 45.8 \\
\hline & Moderate & 129 & 47.3 \\
\hline & Mild & 19 & 7 \\
\hline \multirow[t]{3}{*}{$\begin{array}{l}\text { Ways of identification } \\
\text { for the severity of } \\
\text { disease. }\end{array}$} & $\begin{array}{l}\text { By combined } \\
\text { symptoms } \\
\text { of the disease. }\end{array}$ & 156 & 57.1 \\
\hline & $\begin{array}{l}\text { My child refused } \\
\text { to eat }\end{array}$ & 59 & 21.6 \\
\hline & $\begin{array}{l}\text { The illness continue } \\
\text { for long time }\end{array}$ & 58 & 21.2 \\
\hline \multirow{2}{*}{$\begin{array}{l}\text { Mothers seeking to } \\
\text { traditional healers }\end{array}$} & No & 265 & 97.1 \\
\hline & Yes & 8 & 2.9 \\
\hline \multirow{3}{*}{$\begin{array}{l}\text { Main reasons for } \\
\text { selecting traditional } \\
\text { healers }\end{array}$} & $\begin{array}{l}\text { Don't get cure from } \\
\text { medical care }\end{array}$ & 3 & 37.5 \\
\hline & Treatment is effective & 3 & 37.5 \\
\hline & $\begin{array}{l}\text { Because family } \\
\text { recommend to it }\end{array}$ & 2 & 25 \\
\hline
\end{tabular}

$[\mathrm{AOR}=6.7(2.9,22.2)]$. Mothers who have less than or equal to five family members were almost 6.4 times more likely to seek modern health care than mothers who have greater than five family members $[\mathrm{AOR}=$ $6.4(2.1,20.2)]$ and mothers who perceive as their child illness was severe were five times higher to seek modern health care than mothers who perceive the illness was mild $[\mathrm{AOR}=5.2(1.2,22.6)]$ (Table 4).

\section{Discussion}

In this study $82.1 \%$ mothers were seek modern health care when their child got illness. This finding is similar to a study done in North West Ethiopia $84.4 \%$ mothers were seek modern care [7], higher than a study done in Yemen 51.4\% [3]. However it is lower with a study done in Oromiya region Ethiopia 87\% [8] and urban slum 90\% [9]. This difference may be due to differences in socio demographic characteristics like: educational status, culture, economical status.

The least frequent action in this study was self treatment at home and treatment with holy water which accounts $1.1 \%$. This finding was similar to study carried out in North west Ethiopia only $0.4 \%$ of them treat children illness at home [7] and lower than a study done in Nigeria $34.3 \%$ of them were treated at home [10]. This difference may be due to the presence of health package policy in Ethiopia like: expanding health extension programs, coordinated maternal and child health service and health education packages have been given at large.

In this study $79 \%$ of mothers were decision makers for seeking medical care by their own and the mean length of stay for treatment was two days. This result is similar to study done in Oromiya region Ethiopia [8] mean length of stay for medical treatment is two days, slightly faster than study results in Yemen most of mothers seek medical care after three days of onset of illness [3]. This

Table 4 Factors that affect Health seeking behavior of mothers/care givers among children's having common childhood illness using bivariate and multivariate logistic regression analysis model, in Dangila town, Northwest Ethiopia, 2015

\begin{tabular}{|c|c|c|c|c|c|}
\hline Variables & Response & Yes & No & COR $(95 \% \mathrm{Cl})$ & AOR $(95 \% \mathrm{Cl})$ \\
\hline \multirow[t]{2}{*}{ Mother's age } & $<28$ & 94(34.4) & $30(11)$ & 1 & \\
\hline & $\geq 28$ & 130(47.6) & 19(7) & $2.2(1.2-4.1)$ & $2.4(1.1,5.4)^{*}$ \\
\hline \multirow[t]{2}{*}{ Age of children's } & $\leq 1$ years & 79 (28.9) & $4(1.5)$ & $6.1(2.1-17.7)$ & $6.9(2.9,22.2)^{*}$ \\
\hline & $>1-5$ years & 145(53.1) & $45(16.9)$ & 1 & \\
\hline \multirow[t]{3}{*}{ Marital status of mothers } & Married & 189(69.2) & $31(11.4)$ & $4.1(1.1,15.2)^{*}$ & \\
\hline & Divorced & 29(110.6 & $14(5.1)$ & $1.4(0.3,5.7)$ & \\
\hline & Widowed & $4(1.5)$ & $6(2.2)$ & 1 & \\
\hline \multirow[t]{2}{*}{ Number of family members } & $\leq 5$ & $210(76.9)$ & $39(14.3)$ & $3.8(1.6,9.3)$ & $6.4(2.1,20.2)^{*}$ \\
\hline & $>5$ & $14(5.1)$ & $10(3.7)$ & 1 & \\
\hline \multirow[t]{4}{*}{ Occupation of mothers/caregivers } & House wife & $110(40.3)$ & $24(8.8)$ & $2.1(0.8-5.1)$ & \\
\hline & Government work & $44(16.1)$ & $4(1.5)$ & $4.9(1.4-18.0)$ & \\
\hline & Merchant & $50(18.3)$ & $12(4.4)$ & $1.9(0.1-5.1)$ & \\
\hline & Labor worker & $20(7.3)$ & $9(3.3)$ & 1 & \\
\hline \multirow[t]{3}{*}{ Severity of illness } & Sever & $118(43.2)$ & $7(2.6)$ & $6.0(1.7-21.5)$ & $5.2(1.2,22.6)^{*}$ \\
\hline & Moderate & 92(33.7) & $37(13.6)$ & 0.888(0.3-2.6) & \\
\hline & Mild & $14(5.1)$ & $5(1.8)$ & 1 & \\
\hline
\end{tabular}


could be due to differences in sociodemographic characteristics and health care seeking behavior. This is also related to expansion of urban health extension programs that creates awareness on early health seeking behavior.

Age of mother is one predictor of modern health care seeking behavior. Studies done in Nigeria and Ethiopia $[7,11]$ had reported a positive relationship between maternal age and health care seeking behavior, which is in agreement with the present study. This may be due to as the age of mother increases they will get experiences that help them to easily identify illness and seek medical care.

Mothers who had infants were seven times higher to seek modern care than those mothers who have older children. This finding is comparable to study done in Kenya, health care seeking was highest in the youngest age group (62.9\%) and slowly declined thereafter for older groups $42.5 \%$ [12] and in a study conducted in North West Ethiopia [7]. This may be due to young infants were highly vulnerable to common childhood illness than elder ones and makes mothers to seek modern care easily.

Those mothers who have less than or equal to five family members were around six times higher to seek medical care than to those who have greater than five family members. This result is in line with a study in India those residing in joint family structures are predicting health seeking behaviors [13]. This may be related to low economy of the family and shortage of money for medical treatments.

In the current study, mothers who perceived illness was severe were five times more likely to seek medical care than those who perceive the illness is mild. This finding is similar to a systemic review done in developing countries, study carried out in Yemen and Kenya [3, 12, 14]. This difference may be due to mothers belief of illness will improve by itself and wait until their child show other symptom.

In this study, the main reasons for not seeking modern care were: percived illness was mild 12 (24.5\%), thought sickness is incurable by medicine $8(16.3 \%)$ and shortage of money (2\%) and this is an agreement with studies in Yemen illness was mild (39\%), illness do not need medical treatment (31\%) but contrasts to studies conducted in Amhara region: the disease did not need treatment(31.9\%), bought drugs from drug vendors $(27.2 \%)$, perception of the disease resolves by itself $(56.7 \%)$, lack of money $24 \%[7,15]$.

\section{Conclusion}

The overall health seeking behaviors of mothers who have under five children was $82.1 \%$.Age of the mother, age of the child, family number and perceived severity of illness were the significant factors for health seeking behavior. Recommendation to improve health seeking behavior include: informing the district health office to encourage family planning, educate, support and counsel the community at large and particularly to the women regarding the importance of seeking medical care. Health education about childhood illness in religious places, in schools and in meetings to increase awareness of mothers modern health care seeking behavior.

\section{Limitations}

A limitation of this study was that it assessed only the quantitative aspects of level of modern health care seeking behavior among mothers having under five children. Qualitative study was not incorporated.

\section{Abbreviations}

AOR: Adjusted Odds Ratio; COR: Crude Odds Ratio; EDHS: Ethiopian Demographic Health Survey; FMOH: Federal Ministry of Health; HSB: Health Seeking Behavior; UMR: Under five Mortality Rate; UNICEF: United Nation International Children's Emergency Fund; WHO: World Health Organization

\section{Acknowledgements}

Authors express duly acknowledged the study participants are for voluntarily responding to the questionnaire and for data collectors and supervisors for their cooperation during the field work.

\section{Funding}

The authors received financial support to conduct this study from Addis Ababa University, College of Medicine and Health Science, Addis Ababa, Ethiopia.

\section{Availability of data and materials}

All the data is presented in the main manuscript but can't be shared publically due to presence of sensitive (confidential) participants' information.

\section{Authors' contributions}

$A B, T$ and RM conceived and designed study, collected, analyzed and interpreted data; drafted the manuscript for important intellectual content. The authors reviewed and revised the draft further and approved the final version for submission.

Ethics approval and consent to participate

Ethical clearance obtained from Addis Ababa University, department of nursing and midwifery research committee. All participants provided verbal consent to participate in the study.

\section{Competing interests}

The authors declared that they have no competing interests.

\section{Publisher's Note}

Springer Nature remains neutral with regard to jurisdictional claims in published maps and institutional affiliations.

\section{Author details}

'College of Medicine and Health science, Bahir Dar University, Bahir Dar, Ethiopia. ${ }^{2}$ College of Health Sciences School of Allied Health Sciences, Addis Ababa University, Addis Ababa, Ethiopia.

Received: 9 March 2018 Accepted: 23 May 2018

Published online: 29 May 2018

References

1. WHO. Children: reducing mortality. Geneva (Fact Sheet No 178). 2013.

2. Ministry of Finance and Economic Development, Federal Democratic Republic of Ethiopia. Ethiopia MDGs report 2012. 
3. Webair HH, Bin-Gouth SA. Factors affecting health seeking behavior for common childhood illnesses in Yemen. Patient Preference and Adherence. 2013;7:1129

4. Health Seeking Behaviour. [cited 18 Jan, 2015]; available from: http://ni. unimelb.edu.au/_data/assets/pdf_file/0011/385967/HPHF.

5. Geldsetzer P, Williams TC, Kirolos A, Mitchell S, Ratcliffe LA, Kohli-Lynch MK, et al. The recognition of and care seeking behaviour for childhood illness in developing countries: a systematic review. PLoS One. 2014;9(4):e93427.

6. United Nations (n.d.) Millennium Development Goals website. I2013[cited 21 Jan, 2015]; Availablefrom: http://www.un.org/millenniumgoals/childhealth.shtm.

7. Gelaw YA, Biks GA, Alene KA. Effect of residence on mothers ' health care seeking behavior for common childhood illness. BMC Research Notes. 2014; 7:705

8. Assefa T, Belachew T, Tegegn A, Deribew. Mothers' health care seeking behavior for childhood illnesses. Ethiop J Health Sci. 2008;18(3)

9. Mahejabin F, Parveen S, Ibrahim M. Mother's / care Giver's health seeking behaviour during childhood illness. Original article. 2014:7:5-15.

10. Adegboyega AAOA, Salawu O. Care-seeking behaviour of caregivers for common childhood illnesses in Lagos Island local government area. Nigeria Unbound MEDLINE. 2014;14:65-71.

11. Ajibade BL, Amoo PO, Adeleke MA, Oyadiran GO, Kolade OA, Olagunju RO. Determinants of Mothers Health Seeking Behaviour for Their Children. Journal of Nursing and Health Science. 2013;1(6):9-16.

12. Mbagaya GM, Odhiambo MO, Oniang'o RK. Mother's health seeking behaviour during child illness. Afr Health Sci. 2005;5(4):322-7.

13. Ghosh N Chakrabarti I, Chakraborty M, Biswas R. Factors affecting the healthcareseeking behavior of mothers regarding their children. International Journal of Medicine and Public Health. 2013;3(1)

14. Geldsetzer P, Williams TC, Kirolos A, Mitchell S, Ratcliffe LA, Kohli-Lynch MK, et al. Recognition of and care seeking behaviour for childhood illness in developing countries. PLoS One. 2014;9(4):e93427.

15. Fantahun M, Degu G. Health service utilization in Amhara region of Ethiopia. EthiopJHealth Dev. 2003:17(2):141-7.

\section{Ready to submit your research? Choose BMC and benefit from}

- fast, convenient online submission

- thorough peer review by experienced researchers in your field

- rapid publication on acceptance

- support for research data, including large and complex data types

- gold Open Access which fosters wider collaboration and increased citations - maximum visibility for your research: over $100 \mathrm{M}$ website views per year 